\title{
Co-inoculation of Bradyrhizobium japonicum and Azospirillum brasilense on the physiological quality of soybean seeds
}

\section{Coinoculação de Bradyrhizobium japonicum e Azospirillum brasilense na qualidade fisiológica de sementes de soja}

\author{
Paloma Helena da Silva Libório ${ }^{1 *}$; Ivana Marino Bárbaro-Torneli²; Marco Antonio \\ Nogueira $^{3}$; Sandra Helena Unêda-Trevisoli ${ }^{4}$
}

\section{Highlights:}

Co-inoculation increased protein and mass of thousand seeds of soybean.

Seeds from co-inoculated plants showed higher physiological quality.

Soybean cultivars responded differently to co-inoculation.

\begin{abstract}
The success of the soybean crop depends on the physiological quality of seeds, which can be favored by beneficial microorganisms, however, it may be impaired by unfavorable environmental conditions. The aim of this study was to evaluate the effect of co-inoculation with Bradyrhizobium japonicum and Azospirillum brasilense on the physiological quality of soybean seeds obtained in the 2017/2018 crop season, from a field trial involving 23 cultivars submitted to co-inoculation (in-furrow) or without coinoculation. Plants were assessed for nodulation at R1 and, after harvest at R8, seeds were assessed for concentration of proteins, mass of thousand seeds, and seed physiological quality [(Germination, emergence of seedlings in sand, and Emergence Speed Index (ESI)]. In the average of cultivars, the number of nodules per plant increased from 36.0 in the control to 44.4 nodules with co-inoculation. Increases in the concentration of proteins and in the mass of thousand seeds due to co-inoculation were $5.6 \%$ and $34.7 \%$, respectively. Seeds originated from co-inoculated plants had higher germination rate at the first $(50 \%$ vs. $45.3 \%)$ and at the final $(87 \%$ vs. $79.8 \%)$ countings, in addition to higher rate of seedlings emergence in sand box ( $83.3 \%$ vs. $80 \%)$, and higher ESI (18.5 vs. 17.4). The benefits of coinoculation were observed in 17 of 23 cultivars $(74 \%)$ for at least two of the seven assessed variables. Considering only the minimal germination of $80 \%$, the seeds originated from 10 non-inoculated cultivars could not be used, whereas for the co-inoculated plants this number fell to four.
\end{abstract}

Key words: Diazotrophic bacteria. Emergence speed index. Germination. Glycine max L.

\footnotetext{
Discente do Curso de Doutorado do Programa de Pós-Graduação em Agronomia, Universidade Estadual de Londrina, UEL, Departamento de Agronomia, Londrina, PR, Brasil. E-mail: paloma liborio@hotmail.com

2 Pesquisadora Dra ${ }^{\mathrm{a}}$, Agência Paulista de Tecnologia dos Agronegócios, APTA, Polo Regional Alta Mogiana, Colina, SP, Brasil. E-mail: imarino@apta.sp.gov.br

3 Pesquisador Dr, Empresa Brasileira de Pesquisa Agropecuária, EMBRAPA Soja, Londrina, PR, Brasil. E-mail: marco.nogueira@ embrapa.br

4 Prof $^{a}$ Dr $^{\mathrm{a}}$, Departamento de Produção Vegetal, Universidade Estadual Paulista, UNESP, Jaboticabal, SP, Brasil. E-mail: shu. trevisoli@unesp.br

* Author for correspondence
} 


\section{Resumo}

O sucesso da cultura da soja depende da qualidade fisiológica das sementes, a qual pode ser favorecida por microrganismos benéficos, mas prejudicada por fatores ambientais desfavoráveis. O objetivo desse estudo foi avaliar o efeito da coinoculação com Bradyrhizobium japonicum e Azospirillum brasilense na qualidade fisiológica de sementes de soja obtidas na safra 2017/2018, em ensaio de campo com 23 cultivares, submetidas à coinoculação via sulco de semeadura ou mantidas sem coinoculação. As plantas foram avaliadas quanto à nodulação em R1 e, após a colheita (R8), determinaram-se os teores de proteínas, massa de mil sementes e a qualidade fisiológica das sementes [Germinação, emergência em areia e índice de velocidade de emergência (IVE)]. Na média das cultivares, o número de nódulos aumentou de 36,9 no controle para 44,4 nódulos por planta com a coinoculação. Os aumentos nos teores de proteínas e na massa de mil sementes devido à coinoculação foram de $5,6 \%$ e $34,7 \%$, respectivamente. As sementes das plantas coinoculadas apresentaram maior germinação na primeira contagem $(50,0 \%$ vs. $45,3 \%)$ e na final $(87,0 \%$ vs. $79,8 \%)$, além de maior taxa de emergência de plântulas em caixa de areia $(83,3 \%$ vs. $80,0 \%)$ e maior IVE $(18,5$ vs. 17,4$)$. Os benefícios da coinoculação foram observados em 17 das 23 das cultivares (74\%), em pelo menos duas das sete variáveis avaliadas. Considerando apenas o critério de germinação mínima de $80 \%$, as sementes de 10 cultivares não inoculadas não serviriam para uso, enquanto que para as coinoculadas esse número caiu para quatro.

Palavras-chave: Bactérias diazotróficas. Índice de velocidade de emergência. Germinação. Glycine $\max \mathrm{L}$.

\section{Introduction}

The soybean [Glycine max (L.) Merrill] crop presents great relevance for agriculture and global economy, being Brazil and United States of America (USA) the largest producers. In the 2019/20 crop season, Brazil produced 120.4 million tons, with an average yield of 3,266 $\mathrm{kg} \mathrm{ha}^{-1}$ (Companhia Nacional de Abastecimento [CONAB], 2020).

The success of soybean in Brazil is strongly linked to the development of new cultivars based on new breeding tools and also to the use of high technology, such as inoculants developed over the years of research on the selection of highly efficient $\mathrm{N}$-fixing bacteria, dismissing the use of mineral nitrogen $(\mathrm{N})$ fertilizer.

Inoculats based on Bradyrhizobium spp. have been used in the Brazilian soybean production system since the 1950s. The use of annual inoculation, even in soils with an established population of Bradyrhizobium results in an average gain yield by $8 \%$ (Hungria, Nogueira, \& Araujo, 2015). Recently, the use of a second bacterium in co-inoculation, Azospirillum brasilense, has resulted in $16 \%$ yield increase compared with non- inoculation, increasing the agricultural, economic, social, and environmental sustainability (Hungria et al., 2015). Co-inoculation reached $15 \%$ of the soybean cropped area in the 2018/19 season, amounting to around US\$ 150 million with this technology (Associação Nacional dos Produtores e Importadores de Inoculantes [ANPII], 2019).

Azospirillum is known as Plant GrowthPromoting Bacteria (PGPB) and acts via several mechanisms, including production and secretion of phytohormones (Fukami, Cerezini, \& Hungria, 2018; Cassán et al., 2020). Inoculation or co-inoculation can be done via seeds or simultaneously in the sowing furrow. The latter method was developed as alternative to cope with incompatibility between inoculants and chemicals used in the seed treatment (Hungria et al., 2015).

Bulegon et al. (2016) found different responses of the cultivars BMX Turbo and Coodetec 250 to co-inoculation, who noted an increase in yield for the first one, but not for the second. BárbaroTorneli et al. (2018), evaluating the inoculation and co-inoculation of different soybean cultivars in four locations in the State of São Paulo, found 
that cultivars behaved differently in terms of nodulation, but in general, there were yield gains in response to co-inoculation. These results highlight the effectiveness of co-inoculation in increasing yield, and suggest the existence of genotypic variation in the interaction between soybean and the inoculated microorganisms. In a study by Fipke et al. (2016), soybean cultivars BMX Ativa, TEC 6029 and BMX Potência increased yield by $6 \%$, $4 \%$ and $12 \%$, respectively, due to co-inoculation of Bradyrhizobium spp. and Azospirillum spp..

The physiological quality of soybean seeds reflects their ability to perform vital functions, expressed by germination rate, vigor, and longevity (Marcos, 2013). The speed and synchronism of seed germination and emergence of normal seedlings are essential to reduce the risks related to environmental adversities, contributing for the crop establishment and better expression of potential yield (Krzyzanowski, França, \& Henning, 2018). However, environmental conditions in which the seeds are produced have strong influence on their physiological quality. High temperatures and drought during the crop development and rain at the harvest time are some environmental factors that impair the physiological quality of seeds, reflecting the stress that the plant underwent.

Seeds with high vigor and physiological potential provide greater safety to the farmer, as these seeds are more resistant to adverse conditions. However, despite frequent reports on the beneficial effects of co-inoculation, such as grain yield increase (Hungria et al., 2013, 2015; Bárbaro-Torneli et al., 2018) and greater tolerance to drought (Cerezini et al., 2016; Silva et al., 2019), there are few studies addressing the physiological quality of soybean seeds produced by co-inoculated plants (Queiroz Rego, Cardoso, Cândido, Teodoro, \& Alves, 2018).

The objective of this work was to compare the physiological quality of seeds originated from 23 soybean cultivars co-inoculated with $B$. japonicum and $A$. brasilense in relation to non-inoculated controls.

\section{Materials and Methods}

Field test to evaluate nodulation and obtain seeds

Seeds were obtained in the 2017/2018 crop season, in a non-irrigated area, in the municipality of Guaira-SP, located in the north of the State of São Paulo at $20^{\circ} 20^{\prime} 55^{\prime}$ ' S, $48^{\circ} 19^{\prime} 57^{\prime}$ ' W and 568 $\mathrm{m}$ of altitude. The soil of the experimental area is classified as "Latossolo Vermelho Distrófico" according to the Brazilian classification (Santos et al., 2018). Before the installation of the experiment, samples were taken at the $0-0.20 \mathrm{~m}$ of soil depth for chemical (Raij, Quaggio, Cantarella, \& Abreu, 2001) and granulometric (Day, 1965) analyses: $\mathrm{pH}$ $\left(\mathrm{CaCl}_{2}\right)=5.7$; O.M. $=36 \mathrm{~g} \mathrm{dm}^{-3} ; \mathrm{P}=94 \mathrm{mg} \mathrm{dm}^{-3}$; $\mathrm{K}=5.0$ mmolc dm ${ }^{-3} ; \mathrm{Ca}=63.5 \mathrm{mmolc} \mathrm{dm}^{-3} ; \mathrm{Mg}=$ $16.1 \mathrm{mmolc} \mathrm{dm}^{-3} ; \mathrm{H}+\mathrm{Al}=29.6 \mathrm{mmolc} \mathrm{dm}^{-3} ; \mathrm{V}=$ $74 \%, \mathrm{~S}_{-} \mathrm{SO}_{4}{ }^{2-}=72.7 \mathrm{mg} \mathrm{dm}^{-3}$; Total sand $=245 \mathrm{~g} \mathrm{~kg}^{-}$ 1; Clay $=500 \mathrm{~g} \mathrm{~kg}^{-1}$ and Silt $=253 \mathrm{~g} \mathrm{~kg}^{-1}$. The local climate is subtropical Cwa, with hot and humid summer, and dry winter (Alvares et al., 2013).

Guaíra (SP) belongs to the Macroregion 3 and to the Edaphoclimatic Region (ER) SP 302 (Kaster \& Farias, 2012). Among the 23 assessed cultivars, 15 are recommended for ER SP 302, such as: 1, 3, $4,6,8,9,11,13-16,18$ and 19-21 (Table 1). The remaining cultivars, even not recommended for the region, were evaluated to verify their performance and contribute to increase the supply of new materials to the region.

Before sowing on November 08 2017, seeds were treated with insecticide/fungicide containing fipronil and pyraclostrobin at $2 \mathrm{~mL} \mathrm{~kg}^{-1}$ of seeds of commercial product. For co-inoculation, a liquid inoculant containing B. japonicum (strain SEMIA 5079) and A. brasilense (strains Ab-V5 and Ab-V6) was used at concentrations of $1 \times 10^{9} \mathrm{CFU} \mathrm{mL}^{-1}$ and $1 \times 10^{7} \mathrm{CFU} \mathrm{mL}^{-1}$, respectively, in the same formulation, and applied in-furrow, simultaneously to the sowing, at the rate of $0.45 \mathrm{~L} \mathrm{ha}^{-1}$. 


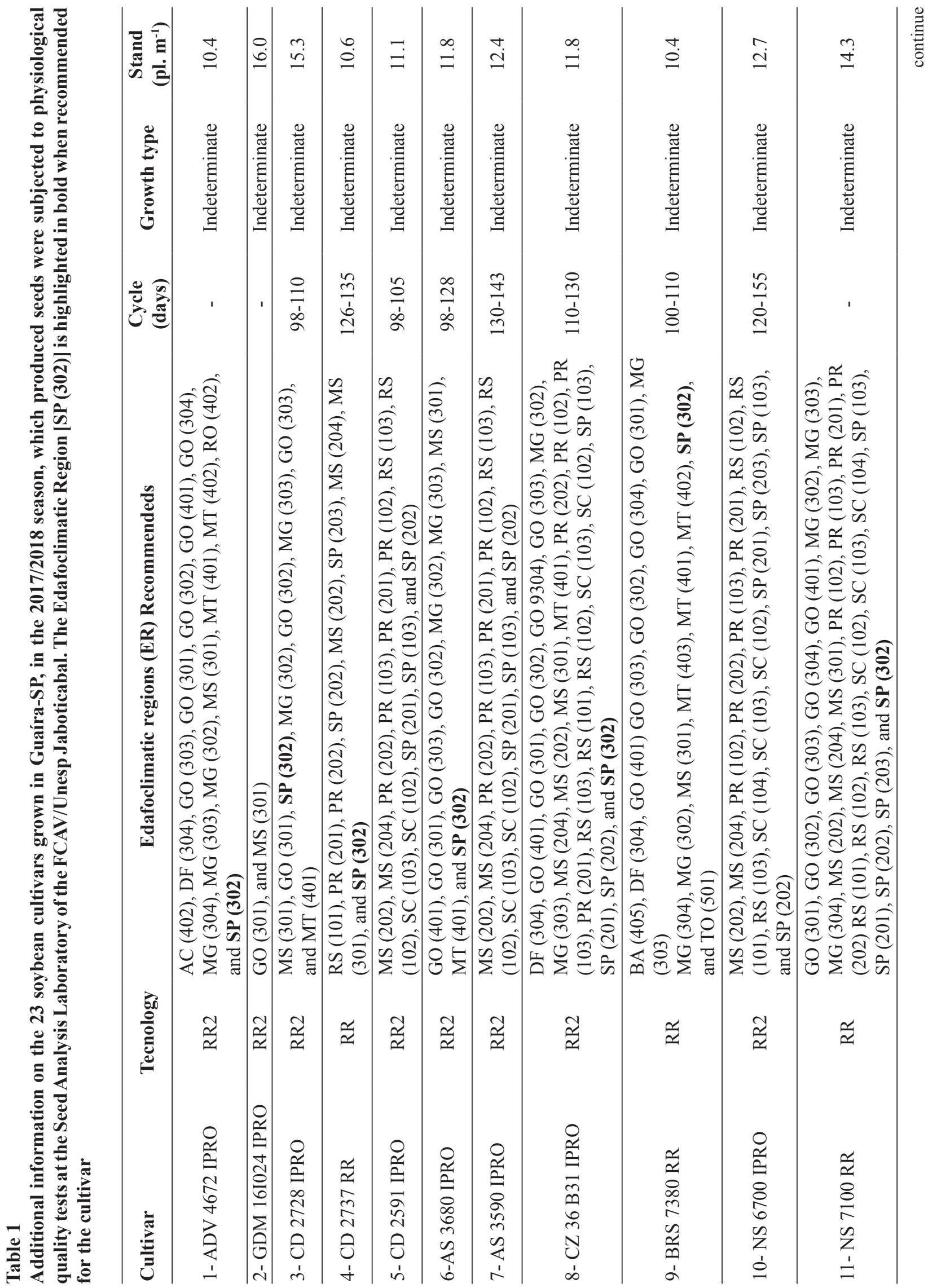




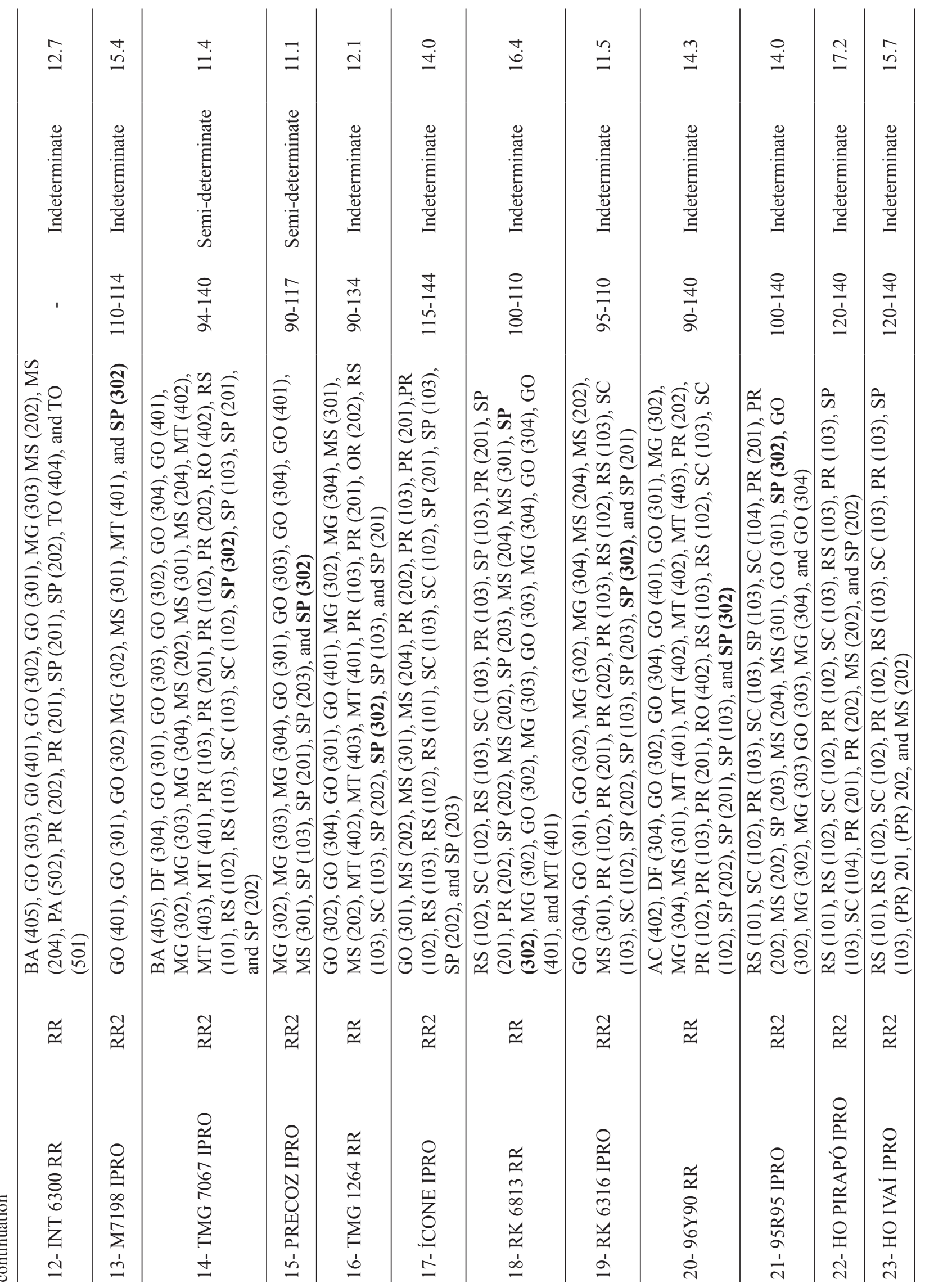


The experiment was in a split-plot design, with three replications. Strips of $60 \times 4 \mathrm{~m}$ for each cultivar were divided transversally, with $30 \mathrm{~m}$ co-inoculated and $30 \mathrm{~m}$ as non-inoculated control. Rows were spaced $0.5 \mathrm{~m}$ apart and the sowing density varied with the recommendation for each cultivar. When the variety had no recommendation for ER SP 302, the recommended density for the most similar ER was used. The sowing fertilization consisted of 330 $\mathrm{kg} \mathrm{ha}^{-1}$ of the 04-23-23 formulae. At R7 stage (Fehr $\&$ Caviness, 1977), the survey of the final stand was carried out by counting the plants in 3 lines of $5 \mathrm{~m}$ per strip (Table 1). At V5 developmental stage (Fehr \& Caviness, 1977), cobalt (Co) and molybdenum (Mo) were applied via leaf spraying $\left(100 \mathrm{~mL} \mathrm{ha}^{-1}\right)$ of commercial product to supply $25 \mathrm{~g}$ of Co and $2 \mathrm{~g}$ of Mo $\mathrm{ha}^{-1}$. Further cultural treatments were done according to the technical recommendation for soybean.
The average temperature during the experimental period (November to March) was $25.5{ }^{\circ} \mathrm{C}$ and the accumulated rainfall was $763.4 \mathrm{~mm}$ (Centro Integrado de Informações Agrometeorológicas [CIIAGRO], 2018). In the first half of December, a drought event was recorded, but did not commit the crop development. Weekly data on temperature, rainfall, evapotranspiration, and water deficit are shown (Figure 1). The harvest was carried out manually on two dates, February 21 and March 03, 2018, according to the maturity of the cultivars. The samples were manually processed and the water content standardized at $13 \%$, stored in paper bags and kept in a cold chamber at $5^{\circ} \mathrm{C}$ until the beginning of germination and emergence tests carried out 30 days after harvest.
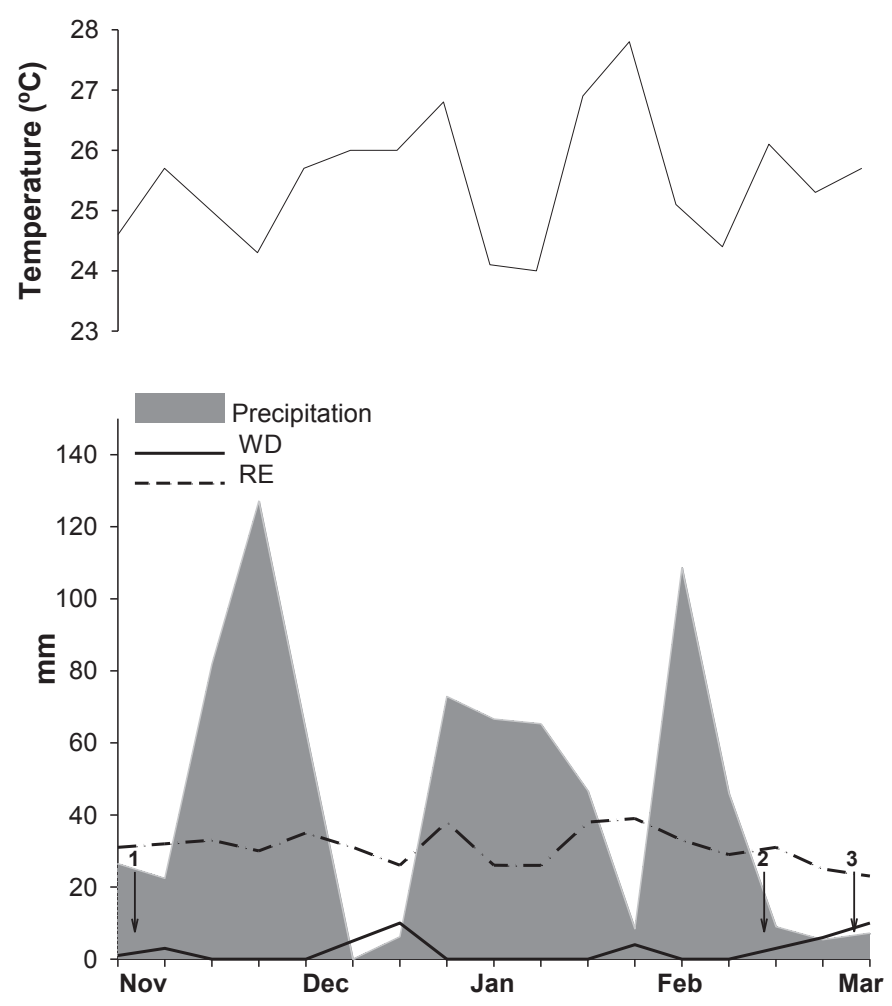

Figure 1. Temperature $\left({ }^{\circ} \mathrm{C}\right)$, precipitation, water deficit(WD) and real evapotranspiration (RE) (mm) every seven days, during 2017/18 growth season in Guaíra-SP. Data were obtained from the weekly water balance reported by Centro Integrado de Informações Agrometeorológicas (CIIAGRO, 2018). Arrow 1 on November 08, 2017 indicates the sowing date; Arrows 2 and 3 on February 21 and March 03, 2018, respectively, indicate the first and second harvest (2: cultivars 5 and $15 ; 3$ : remaining cultivars). 


\section{Number of nodules (NN)}

Nodulation was assessed by direct counting in 10 plants per strip taken at the reproductive stage $\mathrm{R} 1$, in the two central lines, totaling 30 plants per treatment. Roots were washed under tap water on a sieve to prevent the loss of nodules. After drying in an oven with forced air circulation at $60^{\circ} \mathrm{C}$, nodules were removed from roots and counted.

\section{Concentration of protein in seeds (P\%)}

Three 100-g subsamples of each treatment were ground in a Willey type mill, digested in sulfuric acid and catalyzers, and the extract subjected to the Kjeldahl method (Association of Official Analytical Chemists [AOAC], 1995) for determination of total nitrogen, followed by conversion to protein by using the factor 6.25 (Villegas, Ortega Martinez, \& Bauer Mengelberg, 1985).

\section{Mass of thousand seeds (M1000)}

The M1000 was determined at the reproductive stage R8 using the method described in the "Rules for Seed Analysis" adapted for weighing five subsamples of 100 seeds and the average multiplied by 10 , per repetition (Ministério da Agricultura, Pecuária e Abastecimento [MAPA], 2009).

\section{Seed physiological quality}

For germination, emergence, and Emergence Speed Index (ESI) tests, seeds of each cultivar, were pooled and homogenized, forming two sets of seeds per cultivar, with and without co-inoculation. The tests, with four replications, were performed at the Laboratory for Seed Analysis at FCAV / Unesp Jaboticabal.

\section{Germination $(G)$}

Fifty seeds were arranged on sheets of Germitest $^{\circledR}$ paper, using a roll system moistened with distilled water equivalent to 2.5 times the mass of the dry paper, in four repetitions. The rolls were placed in germinators at $25{ }^{\circ} \mathrm{C}$ and $90 \%$ relative air humidity. The first and the last counts were performed on the fifth (G5\%) and on the eighth day (G8\%), respectively, and the results were expressed as a percentage (\%), according to "Rules for Seed Analysis" (MAPA, 2009).

\section{Emergence (E)}

Seeds were placed in plastic trays $(30.2 \times 20.8 \times$ $6.3 \mathrm{~cm}$ ) containing washed and sterilized sand (dry air oven at $200{ }^{\circ} \mathrm{C}$ for $2 \mathrm{~h}$ ). Fifty seeds were sown per tray, at $3 \mathrm{~cm}$ depth, distributed in 5 rows with 10 seeds each, in four replications, totaling two hundred seeds per treatment. Irrigation was performed daily, supplying $450 \mathrm{~mL}$ of distilled water per tray. Daily counting of emerged seedlings was performed until the eighth day, when the number of normal emerged seedlings was recorded and results were expressed in \%, established in "Rules for Seed Analysis" (MAPA, 2009).

\section{Emergence Speed Index (ESI)}

In the last emergence counting, on the eighth day, the ESI was calculated according to Maguire (1962).

$$
\mathrm{ESI}=(\mathrm{E} 1 / \mathrm{N} 1+\mathrm{E} 2 / \mathrm{N} 2+\ldots+\mathrm{En} / \mathrm{Nn})
$$

Where:

$\mathrm{ESI}=$ Emergence Speed Index.

$\mathrm{E} 1, \mathrm{E} 2$ and $\mathrm{En}=$ number of seedlings emerged in each count.

$\mathrm{N} 1, \mathrm{~N} 2$ and $\mathrm{Nn}=$ number of days from sowing until the respective count. 


\section{Statistical analysis}

The dataset was subjected to test of normality (Shapiro \& Wilk, 1965) at 5\% probability. Once the assumptions were fulfilled, analysis of variance were performed using the Scott-Knott test at 5\% probability. The field data were analyzed according to a split-plot design, while the laboratorial data were analyzed according to a completely randomized design with a $23 \times 2$ factorial arrangement. The G5\% data were transformed to $\arcsin V(x / 100)$ and the number of nodules per plant was transformed into $\mathrm{V}(\mathrm{x}+0.5)$ before analysis. All analyses were run with the AgroEstat software (Barbosa \& Maldonado, 2015).

\section{Results and Discussion}

The final stand of plants at R7 stage was not influenced by co-inoculation in any cultivar, so that the results were presented in the average of treatments with and without co-inoculation to characterize the cultivation conditions (Table 1).

For plants evaluated in the field, there was interaction between soybean cultivars and co- inoculation for Number of Nodules (NN), concentration of proteins in seeds, and M1000 (Table 2). For NN, in the unfolding of the interaction, co-inoculation benefited cultivars 1, 4, 7-9, 12, and 20 ; only cultivar 22 had lesser nodulation with coinoculation. Nodulation ranged from 16.3 to 73 nodules per plant without co-inoculation and from 23.9 to 86.0 with co-inoculation. In the average of the cultivars, the increase was from 37 to 44 nodules per plant due to co-inoculation. Co-inoculation also increased the concentration of proteins in the seeds of cultivars 2, 7, 12-15, and 21-23. Concentrations ranged from $29.9 \%$ to $37.6 \%$ among the noninoculated cultivars and from $31.7 \%$ to $37.3 \%$ in the co-inoculated. The average protein concentration in the seeds of the co-inoculated cultivars was $5.6 \%$ higher than in the non-inoculated (from 33.1\% to $35.0 \%$ ). Finally, for M1000, co-inoculation increased the seed density of cultivars 1-8, 14, 1618 , and 21 , but decreased in cultivar 22 . The M1000 produced by the non-inoculated plants ranged from $80 \mathrm{~g}$ to $184.3 \mathrm{~g}$, whereas in the co-inoculated ones ranged from $118 \mathrm{~g}$ to $232.7 \mathrm{~g}$. In the average of cultivars, co-inoculation increased the M1000 from $122.0 \mathrm{~g}$ to $164.4 \mathrm{~g}$. 
Table 2

Number of nodules (NN), protein (P\%) and mass of thousand seeds (M1000) of 23 soybean cultivars co-inoculated with Bradyrhizobium spp. and Azospirillum brasilense (Brady + Azos) or without co-inoculation (control)

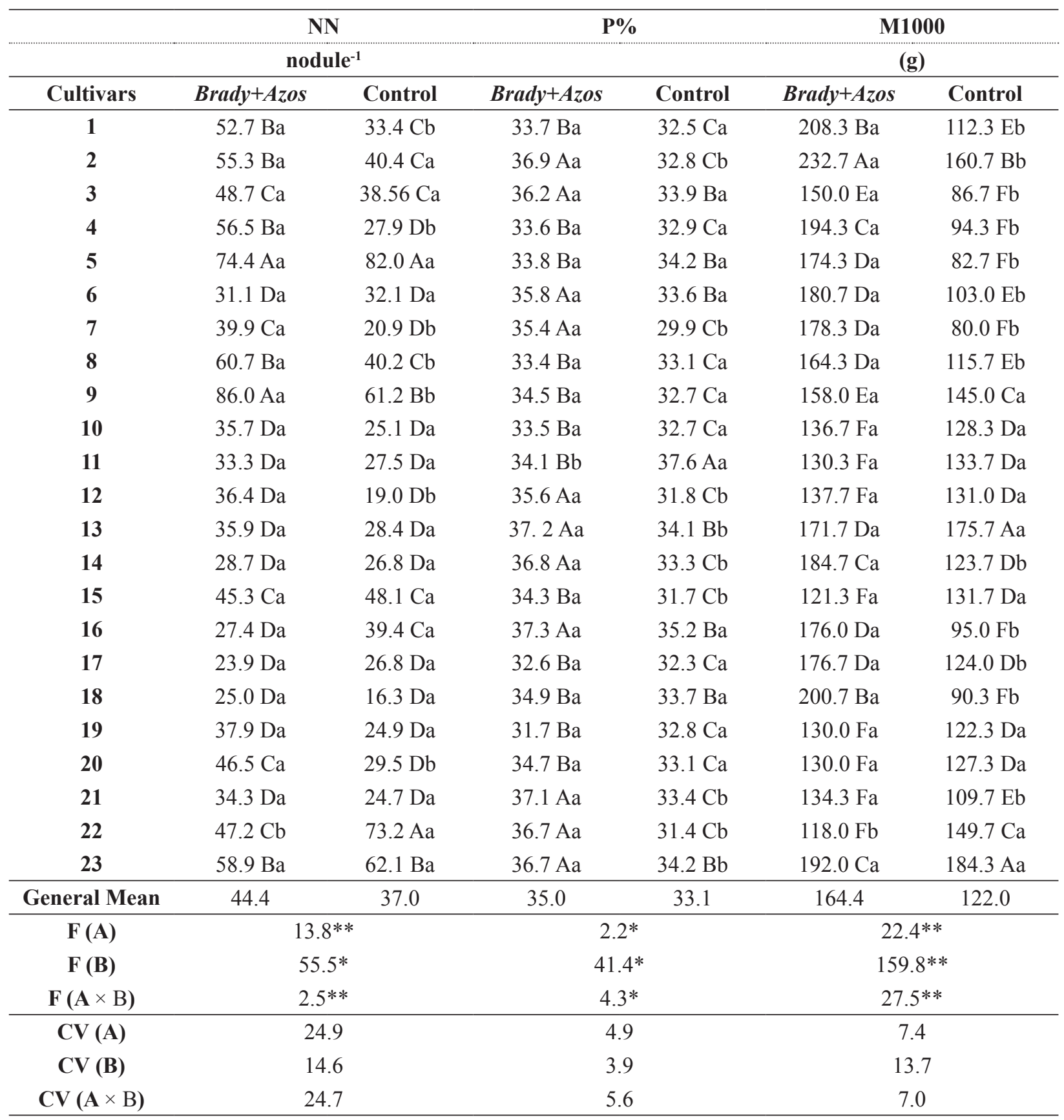

Means followed by the same letter, capital in the column and lowercase in the row, do not differ each other by the Scott-Knott test at $5 \%$ probability. F (A) = cultivars; F (B) = co-inoculation with Bradyrhizobium spp. + Azospirillum brasilense $($ Brady + Azos $) ; \mathrm{F}$ $(\mathrm{A} \times \mathrm{B})=$ cultivar versus co-inoculation interaction.

Although co-inoculation generally results in yield gains (Hungria et al., 2015; Fipke et al., 2016) there might be genotypic differences regarding other variables, like seed density and concentrations of proteins. Genotype-environment interactions may also result in different responses to co-inoculation or inoculation. Interaction between Bradyrhizobium inoculation and varieties on the protein contents in 
soybean grains has also been reported (Zimmer et al., 2016). Genotype interaction was also verified for seed density in the present work. Even though positive responses to co-inoculation were observed for several cultivars, it was negative for cultivar 22, which also presented lower nodulation, but had increased concentration of proteins due to coinoculation. As cultivar 22 is not recommended for ER SP 302, where the trial was performed (Table 1), it may have been impaired in this environment.

Torres et al. (2015) found strong differences between soybean cultivars in terms of nodulation and concentration of proteins in grains, indicating genetic variability, also corroborated by BárbaroTorneli et al. (2018). During soybean reproductive stage, nitrogen $(\mathrm{N})$ from BNF is mostly involved in the concentration of proteins in grains than mineral N (Fabre \& Planchon, 2000) and there is a positive relationship between BNF efficiency and concentration of proteins (Torres et al., 2015). The bacterial isolate in the inoculant can also interfere with the concentration of proteins in grains, without, however, interfering with nodulation and grain density. The protein concentration in grains of soybean inoculated with the most efficient inoculant was up to $26 \%$ higher than the non-inoculated control, for the majority among several cultivars (Zimmer et al., 2016).

The maximization of the BNF, promoted by coinoculation with $A$. brasilense, can further increase protein concentrations in seeds, as observed in nine of 23 cultivars, and an overall increase by $5.6 \%$ in protein concentrations. The relative concentration of protein in grains is one of the most important factors for various industrial applications of soybean. There are several mechanisms by which co-inoculation with $A$. brasilense benefits plant growth and performance, mainly due to production of phytohormones like cytokinins (Fukami et al., 2018) that have positive effects on the protein concentrations in grains (Taiz \& Zeiger, 2002). Gibberellins also produced by PGPBs are involved in the development of the embryo during the seed germination (Cheng et al., 2002). Co-inoculation with $A$. brasilense stimulates an earlier and more abundant nodulation in soybean (Chibeba et al., 2015), resulting in a more efficient BNF process, with greater $\mathrm{N}$ accumulation that results in the formation of denser and more protein-rich seeds.

In addition to intrinsic genotypic variation in the mass of thousand seeds (M1000), co-inoculation also affected this trait (Table 2). The M1000 is considered one of the main yield components in soybean, and co-inoculation provided an increase up to $34.7 \%$ in this trait. Bárbaro-Torneli et al. (2018) also found significant increase in M1000 due to co-inoculation. The hormonal production and regulation promoted by PGPB stimulates photosynthesis, increasing mass allocation in several plant tissues (Battistus et al., 2014), what may have contributed for higher M1000 with co-inoculation. In addition, $A$. brasilense produces indolacetic acid (IAA) (Fukami et al., 2018; Cassán et al., 2020) that stimulates the root system and make it more effective to explore the soil for water and nutrients, providing more resources to the plant to produce denser seeds with higher protein concentrations.

The physiological quality of the seeds originated from the field experiment (assessed by G, E and ESI) was significantly influenced by the interaction between cultivar and co-inoculation (Table 3). In the average of the cultivars, seeds from coinoculated plants had higher germination rate in the first count $(50.0 \%$ vs. $45.3 \%)$ and in the last count $(87.0 \%$ vs. $79.8 \%)$, in addition to higher percentage of emergence in sand (83.3\% vs. $80.0 \%)$ and higher ESI (18.5 vs. 17.4).

In the first count ( 5 days, G5\%), seeds from coinoculated plants of the cultivars $2,9,13$, and 14 showed higher germination rate compared with seeds from plants not co-inoculated. Conversely, cultivars 4 and 20 showed lower germination when seeds were obtained from co-inoculated plants. In the last count (8 days, G8\%), co-inoculation increased the germination rate of cultivars $1(34.5 \%), 3(12.9 \%)$, 9 (17.3\%), 10 (16.4\%), 16 (18.6\%), 19 (17.8\%), 21 $(30.8 \%)$ and $23(24.5 \%)$ in relation to the control. No negative effect of co-inoculation was observed in the G8\% count (Table 3). 
Table 3

Germination percentage in the first count (G5) and in last count (G8), emergence percentage (E) and emergence speed index (ESI) of soybean seeds from 23 co-inoculated cultivars (Brady + Azos) with Bradyrhizobium spp. and Azospirillum brasilense and without co-inoculation (control)

\begin{tabular}{|c|c|c|c|c|c|c|c|c|}
\hline \multirow{3}{*}{ Cultivars } & \multirow{2}{*}{\multicolumn{2}{|c|}{$\begin{array}{c}\text { G5 (\%) } \\
\text { (first count) }\end{array}$}} & \multirow{2}{*}{\multicolumn{2}{|c|}{$\begin{array}{c}\text { G8 }(\%) \\
\text { (last count) }\end{array}$}} & \multicolumn{2}{|c|}{ E (\%) } & \multicolumn{2}{|c|}{ ESI } \\
\hline & & & & & \multirow[b]{2}{*}{$\begin{array}{c}\text { Brady+ } \\
\text { Azos }\end{array}$} & \multirow[b]{2}{*}{ Control } & \multirow[b]{2}{*}{$\begin{array}{c}\text { Brady }+ \\
\text { Azos }\end{array}$} & \multirow[b]{2}{*}{ Contro } \\
\hline & $\begin{array}{c}\text { Brady }+ \\
\text { Azos } \\
\end{array}$ & Control & $\begin{array}{c}\text { Brady }+ \\
\text { Azos } \\
\end{array}$ & Control & & & & \\
\hline 1 & $42.0 \mathrm{Ba}$ & $38.5 \mathrm{Ba}$ & $97.5 \mathrm{Aa}$ & $72.5 \mathrm{Bb}$ & $80.0 \mathrm{Ba}$ & $79.0 \mathrm{Aa}$ & $17.3 \mathrm{Aa}$ & $18.6 \mathrm{Aa}$ \\
\hline 2 & $37.5 \mathrm{Ba}$ & $18.8 \mathrm{Cb}$ & $87.5 \mathrm{Ba}$ & $82.5 \mathrm{Aa}$ & $99.0 \mathrm{Aa}$ & $85.5 \mathrm{Ab}$ & $18.5 \mathrm{Aa}$ & $11.9 \mathrm{Cb}$ \\
\hline 3 & $51.0 \mathrm{Ba}$ & $64.0 \mathrm{Aa}$ & $92.0 \mathrm{Ba}$ & $81.5 \mathrm{Ab}$ & $83.5 \mathrm{Ba}$ & $75.0 \mathrm{Ba}$ & $19.5 \mathrm{Aa}$ & $21.1 \mathrm{Aa}$ \\
\hline 4 & $42.5 \mathrm{Bb}$ & $69.5 \mathrm{Aa}$ & $84.0 \mathrm{Ca}$ & $79.0 \mathrm{Aa}$ & $78.5 \mathrm{Ba}$ & 86.5 Aa & $18.0 \mathrm{Aa}$ & $19.9 \mathrm{Aa}$ \\
\hline 5 & $44.5 \mathrm{Ba}$ & $55.8 \mathrm{Aa}$ & $90.0 \mathrm{Ba}$ & 85.5 Aa & $79.5 \mathrm{Ba}$ & 88.0 Aa & $19.7 \mathrm{Aa}$ & 18.6 Aa \\
\hline 6 & $20.5 \mathrm{Ca}$ & $18.5 \mathrm{Ca}$ & $74.0 \mathrm{Ca}$ & $72.0 \mathrm{Ba}$ & $73.5 \mathrm{Ba}$ & $75.5 \mathrm{Ba}$ & 18.9 Aa & $13.8 \mathrm{Bb}$ \\
\hline 7 & $65.0 \mathrm{Aa}$ & $54.0 \mathrm{Aa}$ & $87.0 \mathrm{Ba}$ & $88.0 \mathrm{Aa}$ & $90.0 \mathrm{Aa}$ & 84.5 Aa & 19.2 Aa & $18.8 \mathrm{Aa}$ \\
\hline 8 & $42.5 \mathrm{Ba}$ & $58.5 \mathrm{Aa}$ & $85.5 \mathrm{Ba}$ & $82.5 \mathrm{Aa}$ & $82.0 \mathrm{Ba}$ & 84.0 Aa & $17.7 \mathrm{Aa}$ & $18.5 \mathrm{Aa}$ \\
\hline 9 & $50.0 \mathrm{Ba}$ & $13.0 \mathrm{Cb}$ & $98.5 \mathrm{Aa}$ & $84.0 \mathrm{Ab}$ & 88.0 Aa & $73.5 \mathrm{Bb}$ & $19.4 \mathrm{Aa}$ & 14.1 Bb \\
\hline 10 & $77.5 \mathrm{Aa}$ & $63.0 \mathrm{Aa}$ & 87.3 $\mathrm{Ba}$ & $75.0 \mathrm{Bb}$ & $82.5 \mathrm{Ba}$ & $78.5 \mathrm{Aa}$ & $19.7 \mathrm{Aa}$ & $18.7 \mathrm{Aa}$ \\
\hline 11 & $21.5 \mathrm{Ca}$ & $22.0 \mathrm{Ca}$ & $87.5 \mathrm{Ba}$ & 85.8 Aa & $73.5 \mathrm{Ba}$ & $59.0 \mathrm{Cb}$ & $13.1 \mathrm{Ba}$ & $12.3 \mathrm{Ca}$ \\
\hline 12 & $20.0 \mathrm{Ca}$ & $22.5 \mathrm{Ca}$ & $74.0 \mathrm{Ca}$ & $73.8 \mathrm{Ba}$ & $69.0 \mathrm{Ba}$ & $72.5 \mathrm{Ba}$ & $14.5 \mathrm{Ba}$ & 14.4 $\mathrm{Ba}$ \\
\hline 13 & $68.5 \mathrm{Aa}$ & $44.5 \mathrm{Ab}$ & $81.5 \mathrm{Ca}$ & $75.5 \mathrm{Ba}$ & $83.5 \mathrm{Ba}$ & $81.0 \mathrm{Aa}$ & $20.2 \mathrm{Aa}$ & 17.6 Aa \\
\hline 14 & $67.0 \mathrm{Aa}$ & $17.5 \mathrm{Cb}$ & $80.0 \mathrm{Ca}$ & 81.0 Aa & $81.5 \mathrm{Ba}$ & 71.5 $\mathrm{Ba}$ & $19.6 \mathrm{Aa}$ & $11.2 \mathrm{Cb}$ \\
\hline 15 & $79.0 \mathrm{Aa}$ & 81.0 Aa & $74.8 \mathrm{Ca}$ & $70.3 \mathrm{Ba}$ & $79.5 \mathrm{Ba}$ & 88.5 Aa & $21.0 \mathrm{Aa}$ & 19.2 Aa \\
\hline 16 & $77.0 \mathrm{Aa}$ & $60.0 \mathrm{Aa}$ & $84.8 \mathrm{Ba}$ & $71.5 \mathrm{Bb}$ & $88.0 \mathrm{Aa}$ & 84.0 Aa & 17.7 Aa & 19.2 Aa \\
\hline 17 & $59.0 \mathrm{Aa}$ & $51.5 \mathrm{Aa}$ & $92.0 \mathrm{Ba}$ & 87.0 Aa & $89.0 \mathrm{Aa}$ & $82.5 \mathrm{Aa}$ & $19.9 \mathrm{Aa}$ & $20.8 \mathrm{Aa}$ \\
\hline 18 & $57.0 \mathrm{Aa}$ & $54.0 \mathrm{Aa}$ & $92.5 \mathrm{Ba}$ & $92.0 \mathrm{Aa}$ & $98.0 \mathrm{Aa}$ & $95.5 \mathrm{Aa}$ & $20.6 \mathrm{Aa}$ & $20.2 \mathrm{Aa}$ \\
\hline 19 & $41.0 \mathrm{Ba}$ & $40.3 \mathrm{Ba}$ & $94.8 \mathrm{Aa}$ & $80.5 \mathrm{Ab}$ & $74.0 \mathrm{Ba}$ & $80.5 \mathrm{Aa}$ & 18.6 Aa & 17.7 Aa \\
\hline 20 & $40.0 \mathrm{Bb}$ & $60.0 \mathrm{Aa}$ & $75.5 \mathrm{Ca}$ & $83.5 \mathrm{Aa}$ & $75.5 \mathrm{Ba}$ & $66.5 \mathrm{Ca}$ & 17.4 Aa & 19.2 Aa \\
\hline 21 & $21.3 \mathrm{Ca}$ & $16.5 \mathrm{Ca}$ & $91.3 \mathrm{Ba}$ & $69.8 \mathrm{Bb}$ & $94.0 \mathrm{Aa}$ & $81.0 \mathrm{Ab}$ & $15.4 \mathrm{Ba}$ & 15.6 Ba \\
\hline 22 & $56.5 \mathrm{Aa}$ & $58.0 \mathrm{Aa}$ & $91.0 \mathrm{Ba}$ & 83.5 Aa & $77.5 \mathrm{Ba}$ & $79.5 \mathrm{Aa}$ & 19.1 Aa & $19.8 \mathrm{Aa}$ \\
\hline 23 & $71.0 \mathrm{Aa}$ & $59.5 \mathrm{Aa}$ & $99.0 \mathrm{Aa}$ & $79.5 \mathrm{Ab}$ & $96.5 \mathrm{Aa}$ & $88.0 \mathrm{Aa}$ & 19.4 Aa & $17.7 \mathrm{Aa}$ \\
\hline $\begin{array}{c}\text { General } \\
\text { Mean }\end{array}$ & 50.0 & 45.3 & 87.0 & 79.8 & 83.3 & 80.0 & 18.5 & 17.4 \\
\hline F (A) & \multicolumn{2}{|c|}{$15.2 * *$} & \multicolumn{2}{|c|}{$6.3 * *$} & \multicolumn{2}{|c|}{$6.0 * *$} & \multicolumn{2}{|c|}{$8.5^{* *}$} \\
\hline F (B) & \multicolumn{2}{|c|}{$7.3^{* *}$} & \multicolumn{2}{|c|}{$58.1^{* *}$} & \multicolumn{2}{|c|}{$7.2 * *$} & \multicolumn{2}{|c|}{$12.5^{* *}$} \\
\hline $\mathbf{F}(\mathbf{A} \times \mathrm{B})$ & \multicolumn{2}{|c|}{$3.8^{* *}$} & \multicolumn{2}{|c|}{$3.1^{* *}$} & \multicolumn{2}{|c|}{$1.6^{*}$} & \multicolumn{2}{|c|}{$3.9 * *$} \\
\hline CV (\%) & \multicolumn{2}{|c|}{18.2} & \multicolumn{2}{|c|}{7.7} & \multicolumn{2}{|c|}{10.2} & \multicolumn{2}{|c|}{11.4} \\
\hline
\end{tabular}

Means followed by the same letter, capital in the column and lowercase in the row, do not differ each other by the Scott-Knott test at $5 \%$ probability. F (A) = cultivars; F (B) = co-inoculation with Bradyrhizobium spp. + Azospirillum brasilense $($ Brady + Azos $) ; \mathrm{F}$ $(\mathrm{A} \times \mathrm{B})=$ cultivar versus co-inoculation interaction. 
During germination, accumulated reserves in the embryo are initially metabolized, followed by components in the reserve tissues, which are mobilized by activity of hydrolytic enzymes to facilitate the flow of soluble compounds to the growing regions (Carvalho \& Nakagawa, 2000). Thus, co-inoculated plants were better nourished and produced seeds with higher germinative capacity due to greater nutritional and energy reserves. Henning et al. (2010), evaluating the chemical composition and mobilization of reserves in high- and low-vigor soybean seeds, found that more vigorous seeds had higher M1000 than less vigorous seeds. Considering the average of genotypes, the increase in seed density due to coinoculation coincided with the germination rate with eight days (G8\%), although individually this correspondence occurred only for cultivars $1,3,16$, and 21 , indicating that more factors are involved in the G8\% than solely M1000.

According to Normative Instruction 45 of MAPA (2013), soybean seeds must have a minimum germination of $80 \%$ and purity of $99 \%$. Considering only this criterion, the seeds of 10 nonco-inoculated cultivars would no longer be suitable for use, whereas for co-inoculated plants the number below $80 \%$ germination dropped to only four (Table 3), indicating that, despite the unfavorable conditions of the site used for seed production (high temperatures, drought and rainfall during the harvest - Figure 1), co-inoculation improved seed physiological quality. Production of high-quality seeds requires that maturation and harvesting phases occur under drier conditions and mild temperatures. These conditions can be found in tropical regions in areas with altitude above $700 \mathrm{~m}$ (Peske, Villela, $\&$ Meneghello, 2012). However, the altitude of the experimental site is $568 \mathrm{~m}$, what may explain the high occurrence of seeds with germination below $80 \%$, especially from plants not co-inoculated.

Considering the percentage of normal seedlings emergence in sand, seeds of cultivars 2, 9, 11, and 21, had higher rates when obtained from co-inoculated plants. Cultivars 2, 6, 9, and 14 also had higher ESI when seeds came from co-inoculated plants. Higher ESI values are related to a rapid emergence, higher contents of soluble proteins, and greater capacity to mobilize reserves for germination, ensuring more vigorous initial seedling development (Henning et al., 2010). These findings corroborate Queiroz Rego et al. (2018), who reported that seeds with higher physiological quality came from plants co-inoculated with Bradyrhizobium spp. and Azospirillum spp.

In general, cultivars 1-3, 5-7, 9, 10, 13-19, 21, and 23 were responsive to co-inoculation in at least two out of seven assessed traits, in field and laboratory analyzes, representing $74 \%$ of the cultivars, from which 1, 3, 6, 9, 13-16, 18, 19, and 21 are indicated for the ER SP (302) region. However, except for cultivar 2 , cultivars $5,7,10,12,17,22$, and 23 , which are not recommended for the region, even though some have been favored by co-inoculation (5, 7 and 17), presented the lowest values of M1000, indicating non-adaptation for cultivation in ER SP (302) region.

\section{Conclusions}

The response to co-inoculation depends on the cultivar and the considered trait, but in most cases the effect is positive.

Increases in soybean nodulation, concentration of proteins in seeds and seed density promoted by co-inoculation had no direct relationship with the improvement of seed physiological quality for most cultivars, indicating that other factors favored by coinoculation are involved in the seed physiological quality.

\section{References}

Alvares, C. A., Stape, J. L., Sentelhas, P. C., Moraes, G. de, Leonardo, J., \& Sparovek, G. (2013). Köppen's climate classification map for Brazil. Meteorologische Zeitschrift, 22(6), 711-728. doi: 10.1127/0941-2948/2013/0507 
Associação Nacional dos Produtores e Importadores de Inoculantes (2019). Inoculantes em alta. Recuperado de http://www.anpii.org.br/inoculantes-em-alta/

Association of Official Analytical Chemists (1995). Official methods of analysis (16nd ed.). Washington, D.C.: AOAC.

Bárbaro-Torneli, I. M., Finoto, E. L., Borges, W. L. B., Tokuda, F. S., Santos, G. X. L., Martins, M. H.,... Mateus, G. P. (2018). Evaluation of soybean cultivars in the State of São Paulo in response to the application of inoculants in the sowing furrow. Nucleus, (Ed. Esp.), 55-62. doi: 10.3738/1982.2278. 3001

Barbosa, J. C., \& Maldonado, W., Jr. (2015). Agronomic experimentation and AgroEstat: system for statistical analysis of agronomic trials. Jaboticabal, SP: Multipress.

Battistus, A. G., Hachmann, T. L., Mioranza, T. M., Muller, M. A., Madalosso, T., Favorito, P. A.,... Bulegon, L. G. (2014). Synergistic action of Azospirillum brasilense combined with thiamethoxam on the physiological quality of maize seedlings. African Journal of Biotechnology, 13(49), 4501-4507 doi: 10.5897/AJB2014.14059

Bulegon, L. G., Rampim, L., Klein, J., Kestring, D., Guimarães, V. F., Battistus, A. G., \& Inagaki, A. M. (2016). Components of production and yield of soybean inoculated with Bradyrhizobium and Azospirillum. Terra Latinoamericana, 34(2), 169176.

Carvalho, N. M.; Nakagawa, J. (2000). Sementes: Ciência, Tecnologia e Produção. Jaboticabal, São Paulo: FUNEP, 4(1), 588.

Cassán, F., Coniglio, A., López, G., Molina, R., Nievas, S., de Carlan, C. Le N.,... Mora, V. (2020). Everything you must know about Azospirillum and its impact on agriculture and beyond. Biology and Fertility of Soils, 56(1), 461-479. doi: 10.1007/s00374-02001463-y

Centro Integrado de Informações Agrometeorológicas (2018). Balanço hídrico semanal em Guaíra-SP, de 01/11/2017 a 01/03/2018. São Paulo, Brasil. Recuperado de http://www. ciiagro.sp.gov.br/

Cerezini, P., Kuwano, B. H., Santos, M. B. dos, Terassi, F., Hungria, M., \& Nogueira, M. A. (2016). Strategies to promote early nodulation in soybean under drought. Field Crops Research, 196(1), 160167. doi: 10.1016/j.fcr.2016.06.017
Cheng, W. H., Endo, A., Zhou, L., Penney, J., Chen, H. C., Arroyo, A.,... Koshiba, T. (2002). A unique short-chain dehydrogenase/reductase in Arabidopsis glucose signaling and abscisic acid biosynthesis and functions. The Plant Cell, 14(11), 2723-2743. doi: 10.1105/tpc.006494

Chibeba, A. M., Guimarães, M. de F., Brito, O. R., Nogueira, M. A., Araujo, R. S., \& Hungria, M. (2015) Co-inoculation of soybean with Bradyrhizobium and Azospirillum promotes early nodulation. American Journal of Plant Sciences, 6(10), 1641-1649. doi: 10.4236/ajps.2015.610164

Companhia Nacional de Abastecimento (2020). Nono levantamento de grãos. Safra 2019/20. Recuperado de https://www.conab.gov.br/info-agro/safras/graos

Day, P. R. (1965). Particle fractionation and particle-size analysis. Methods of Soil Analysis: Part 1 Physical and Mineralogical Properties, Including Statistics of Measurement and Sampling, 9(1), 545-567. doi: 10.2134/agronmonogr9.1.c43

Fabre, F., \& Planchon, C. (2000). Nitrogen nutrition, yield and protein content in soybean. Plant Science, 152(1), 51-58. doi: 10.1016/S0168-9452(99)002216

Fehr, W. R., \& Caviness, C. E. (1977). Stages of soybean development: Special Report. Recuperado de https:// lib.dr.iastate.edu/cgi/viewcontent.cgi? article $=1076$ \&context $=$ specialreports

Fipke, G. M., Conceição, G. M., Grando, L. F. T., Ludwig, R. L., Nunes, U. R., \& Martin, T. N. (2016). Co-inoculation with diazotrophic bacteria in soybeans associated to urea topdressing. Ciência $e$ Agrotecnologia, 40(5), 522-533. doi: 10.1590/141370542016405001316

Fukami, J., Cerezini, P., \& Hungria, M. (2018). Azospirillum: benefits that go far beyond biological nitrogen fixation. $A M B$ Express, 8(1), 73. doi: 10.1186/s13568-018-0608-1

Henning, F. A., Mertz, L. M., Jacob, E. A., Jr., Machado, R. D., Fiss, G., \& Zimmer, P. D. (2010). Chemical composition and reserve mobilization in soybean seeds with high and low vigor. Bragantia, 69(3), 727-734. doi: 10.1590/S0006-87052010000300026

Hungria, M., Nogueira, M. A., \& Araujo, R. S. (2015). Soybean seed co-inoculation with Bradyrhizobium spp. and Azospirillum brasilense: a new biotechnological tool to improve yield and sustainability. American Journal of Plant Sciences 6(6), 811-817. doi: 10.4236/ajps.2015.66087 
Hungria, M., Nogueira, M. A., \& Araujo, R. S. (2013). Co-inoculation of soybeans and common beans with rhizobia and azospirilla: strategies to improve sustainability. Biology and Fertility of Soils, 7(49), 791-801. doi: 10.1007/s00374-012-0771-5

Kaster, M., \& Farias, J. R. B. (2012). Regionalization of cultivation and use value tests and indication of soybean cultivars-third approximation. (Documents, INFOTECA-E). Londrina: EMBRAPA Soja.

Krzyzanowski, F. C., França, J. B., Neto, \& Henning, A. A. (2018). A alta qualidade da semente de soja: fator importante para a produção da cultura (Circular Técnica, $\mathrm{n}^{\circ}$ 136). Londrina: EMBRAPA Soja. Recuperado de https://ainfo.cnptia.embrapa.br/ digital/bitstream/item/177391/1/CT136-online.pdf

Maguire, J. D. (1962). Speed of germination aid in selection and evaluation for seedling emergence and vigor 1. Crop science, 2(2), 176-177. doi: $10.2135 / \mathrm{cr}$ opsci1962.0011183X000200020033x

Marcos, J. F⿳..(2013). Importância do potencial fisiológico da semente de soja. Informativo Abrates, 23(1), 2124. Recuperado de https://www.abrates.org.br/img/ informations/950ff7fa-c03a-4960-a520-f6cb0870 babe_IA \% 20vol.23\%20n.1.pdfApage $=21$

Ministério da Agricultura, Pecuária e Abastecimento. (2009). Regras para análise de sementes. Secretaria de Defesa Agropecuária. MAPA/ACS.

Ministério da Agricultura, Pecuária e Abastecimento (2013). Instrução Normativa 45. Recuperado de http://antigo.agricultura.gov.br/assuntos/insumosagropecuarios/insumos-agricolas/sementes-emudas/ publicacoes-sementes-e-mudas/copy_of INN45de17desetembrode2013.pdf

Peske, S., Villela, F. A., \& Meneghello, G. E. (2012). Seeds: scientific and technological foundations. Pelotas: UFPel.

Raij, B., Quaggio, J. A., Cantarella, H., \& Abreu, C. A. (2001). The chemical analysis methods of the IAC soil analysis system in the national context. Chemical Analysis to Assess Fertility of Tropical Soils (pp. 5-39). Campinas, SP.
Queiroz Rego, C. H., Cardoso, F. B., Silva Cândido, A. C., Teodoro, P. E., \& Alves, C. Z. (2018). Coinoculation with Bradyrhizobium and Azospirillum increases yield and quality of soybean seeds. Agronomy Journal, 110(6), 2302-2309. doi: 10.2134/ agronj2018.04.0278

Santos, H. G., Jacomine, P. K. T., Anjos, L. H. C. dos, Oliveira, V. A. de, Lumbreras, J. F., Coelho, M. R.,... Cunha, T. J. F. (2018). Brazilian system of soil classification. Brasília, DF: EMBRAPA.

Shapiro, S. S., \& Wilk, M. B. (1965). An analysis of variance test for normality (complete samples). Biometrika, 52(3/4), 591-611. doi: 10.2307/2333709

Silva, E. R., Zoz, J., Oliveira, C. E. S., Zuffo, A. M., Steiner, F., Zoz, T., \& Vendruscolo, E. P. (2019). Can co-inoculation of Bradyrhizobium and Azospirillum alleviate adverse effects of drought stress on soybean (Glycine max L. Merrill.)? Archives of Microbiology, 201(3), 325-335. doi: 10.1007/s00203-018-01617-5

Taiz, L. Z., \& Zeiger, E. E. (2002). Plant physiology.

Torres, A. R., Grunvald, A. K., Martins, T. B., Santos, M. A. D., Lemos, N. G., Silva, L. A. S., \& Hungria, M. (2015). Genetic structure and diversity of a soybean germplasm considering biological nitrogen fixation and protein content. Scientia Agricola, 72(1), 47-52. doi: 10.1590/0103-9016-2014-0039

Villegas, E., Ortega Martinez, E. I., \& Bauer Mengelberg, J. R. (1985). Chemical methods used at CIMMYT for determining protein quality in cereal grains. CIMMYT.

Zimmer, S., Messmer, M., Haase, T., Piepho, H. P., Mindermann, A., Schulz, H.,... Heß, J. (2016). Effects of soybean variety and Bradyrhizobium strains on yield, protein content and biological nitrogen fixation under cool growing conditions in Germany. European Journal of Agronomy, 72(1), 38-46. doi: 10.1016/ j.eja.2015.09.008 